\title{
The Groningen Case: When Science Becomes Part of the Problem, Not the Solution
}

\section{INTRODUCTION}

The Groningen case is exemplary of the quest, by both society and the scientific community, to deal with induced seismicity. Although induced earthquakes have already been recognized for decades in relationship to mining and water impoundment behind dams (e.g., Klose, 2010; Foulger et al., 2018), in recent years induced seismicity has become a global issue of public concern, in particular in relationship to hydrocarbon production, hydraulic fracturing, and wastewater disposal (e.g., Keranen and Weingarten, 2018). In the future, hazards emanating from induced seismicity will remain a matter of public concern, especially with further developments in, for example, geothermal energy production and carbon sequestration.

At least since the 1990s, the northern Dutch province of Groningen, situated on top of one of the largest gas fields in the world, has been plagued by minor earthquakes induced by gas extraction. Although the impact of the induced seismicity was initially played down and seen as miscellaneous news, everything changed on 16 August 2012. That day, a minor M 3.6 earthquake rattled the region around the little village of Huizinge. This was, and to date still is, the strongest induced earthquake ever recorded in Groningen. The people living on top of the gas field, as well as local, regional, and national policymakers, the operator (Nederlandse Aardolie Maatschappij [NAM]), and the scientific community were all taken by surprise. What followed was a downward spiral of distrust and outrage by local communities and people afflicted by damage to their properties, not only toward policymakers but also toward the scientific community. The induced earthquakes, which were at first a day-to-day problem, triggered an institutional crisis, leading to a complete breakdown of the perceived legitimacy of the gas production policy sector (Schmidt et al., 2018). Ever since, policy makers have attempted to restore their legitimacy but have failed to cash in on the multiple windows of opportunity to do so.

Over the last five years, I have had the privilege to visit, listen, and talk to a lot of people involved in the Groningen case, including the Groningen people burdened by the consequences of the induced seismicity, local, regional, and national policymakers, colleagues at different scientific institutes and universities, the regulator (Staatstoezicht op de Mijnen [SodM]), and the operator (NAM). As a Belgian, Dutch-speaking, earth scientist who is not involved in any research in Groningen that is financed by the operator or Dutch funding agencies, I have also been regularly solicited by the Dutch media to comment on developments in the Groningen case as an independent observer. Following the Groningen case, social media, in particular Twitter, turned out to be an ideal instrument to probe the intentions of activists, the opinions of politicians, and the emotions of the Groningen people afflicted, as well as the official positions of the operator, regulator, or authorities on key moments, such as a felt earthquake, a governmental decision, or a demonstration. The opportunity to get acquainted with the perspectives of most parties involved in the Groningen case eventually enabled me to get a rather comprehensive overview of the "wicked problem" (Steckler et al., 2018) that the Groningen case has become. In this article, I specifically reflect on the role that scientists played in the way the Groningen case has been mismanaged. Indeed, the question needs to be asked whether or not the scientific community failed to properly inform the public to enable them to assess their personal risk perception and to advise policymakers to allow them to take effective measures.

It has become evident that each case of induced seismicity is unique (e.g., Keranen and Weingarten, 2018). No one-sizefits-all solution for managing risks caused by induced earthquakes exists. In the end, it remains a continuous learning process for all parties involved. But I am convinced that lessons can be learned from the Groningen case that can be inspirational to scientists involved in risk management and communication in other cases of induced seismicity.

\section{THE GRONINGEN GAS FIELD}

The Groningen gas field, also known as the Slochteren gas field, located in the northeastern part of the Netherlands, is one of the largest gas fields in the world (de Jager and Visser, 2017). It is estimated to contain around 2900 billion $\mathrm{m}^{3}$ (bcm) of gas; today some $75 \%$ has been produced. After more than 50 yrs of production, the field is close to the phase of declining production and phasing out.

The reservoir, $45 \times 25 \mathrm{~km}$ in area, is situated at $\sim 3 \mathrm{~km}$ depth in a $\sim 350 \mathrm{~m}$ thick, highly permeable, Permian sandstone formation, called the Slochteren Formation, capped by Zechstein salt (de Jager and Visser, 2017). The reservoir is 


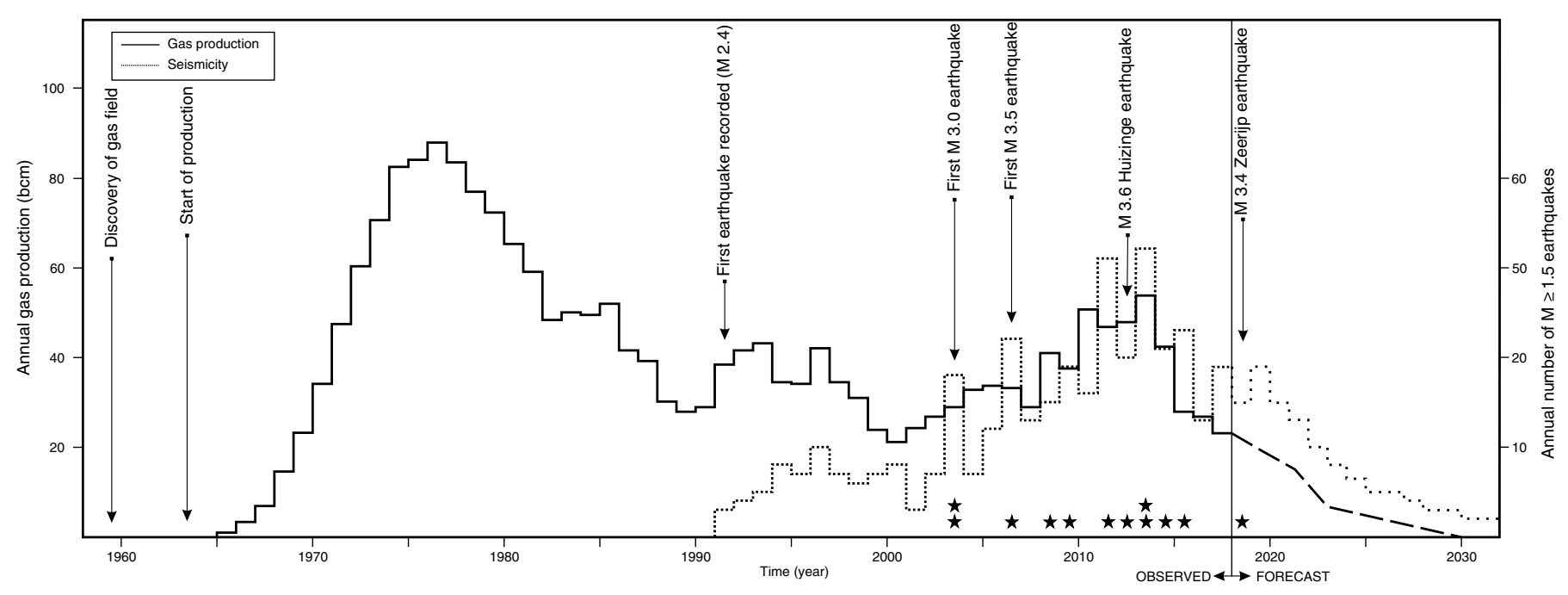

A Figure 1. History of induced seismicity (annual number of $\mathbf{M} \geq 1.5$ earthquakes) and annual gas production (bcm/yr) in Groningen with indication of some key moments (data from Nederlandse Aardolie Maatschappij [NAM], 2018a). Forecast of gas production is based on the governmental decision on the phase out by 2030 (Rijksoverheid, 2018); forecast of seismicity is based on the simulations of Staatstoezicht op de Mijnen (SodM, 2018). Stars indicate $\mathbf{M} \geq 3.0$ earthquakes.

transected by many predominantly normal faults that are related to a late Jurassic-early Cretaceous rifting event. The faults are, to a large extent, permeable to gas flow.

The Groningen gas has a high content of nitrogen $(\sim 14 \%)$, being a low calorific gas (de Jager and Visser, 2017). The high dependency on this particular type of gas in the Netherlands, Belgium, and Germany for household heating and cooking, makes the Groningen case not only a national problem but also an international issue with respect to future security of supply of low-calorific Groningen gas to these countries.

The Groningen gas field was accidentally discovered in 1959 (Fig. 1). Production started in 1963. The early 1970s were characterized by a high-rate production (up to $90 \mathrm{bcm} /$ yr; Fig. 1). Afterward production was reduced (up to $21 \mathrm{bcm} / \mathrm{yr}$ ) in 2000. Production increased again (up to $54 \mathrm{bcm} / \mathrm{yr}$ ) in 2013, the year after the Huizinge earthquake. Since 2014, a systematic reduction of production has been imposed by the regulator (SodM), with the hope to reduce the induced seismicity (de Waal et al., 2017). After rising protest following the M 3.4 Zeerijp earthquake in January 2018, to date the second strongest earthquake after the 2012 Huizinge earthquake, the Dutch government hastily decided to definitively phase out the Groningen gas field by 2030 (Fig. 1), leaving around $10 \%$ of the gas in the reservoir (Rijksoverheid, 2018). The operator will be confronted with a stranded asset of more than 50 billion euro, and the Dutch government with a substantial loss of revenue.

\section{INDUCED SEISMICITY}

The first induced earthquake, with a magnitude of $\mathbf{M} 2.4$, was recorded in 1991, nearly 30 yrs after production started (Fig. 1). Because of the limitations of the seismic network at that time, it is not known whether seismic activity was already present before 1991 (Dost et al., 2017). The first M 3.0 earthquake occurred in 2003 and the first M 3.5 earthquake in 2006 (Fig. 1). Seismicity rate increased significantly in 2003, seemingly unrelated to physical changes in the reservoir (Dost et al., 2017). In total, more than 1250 earthquakes have been recorded since 1991 (1252 on 31 August 2018), of which 12 earthquakes had a magnitude equal to or larger than $\mathbf{M} 3.0$ (Fig. 1), and 91 earthquakes had a magnitude between M 2.0 and 3.0. Nearly all seismic activity has been confined to the reservoir with hypocenters around $3 \mathrm{~km}$ depth. Earthquakes with magnitudes of $\mathbf{M} 1.8$ and higher are reported to be felt by people, whereas earthquakes with magnitudes of $\mathbf{M} 2.0$ and higher have caused nonstructural damage to buildings (e.g., cracks) (de Waal et al., 2017). In the beginning of the $1990 \mathrm{~s}$, the maximum expected magnitude was estimated around $\mathbf{M}$ 3.0, however this value was systematically raised to about M 4.0 prior to the 2012 Huizinge earthquake and M 5.0 after the Huizinge earthquake (de Waal et al., 2017).

It is commonly accepted that the induced earthquakes are primarily the result of the compaction of the reservoir sandstone as a consequence of depletion, causing extra stress on critically stressed faults transecting the reservoir (e.g., Bourne et al., 2014). The inferred relationship between production and seismicity led to the belief that the induced seismicity is controllable. Based on that belief, the regulator has now forecast a rapidly decreasing seismicity in relation to the phase out of the gas field by 2030 (Fig. 1; Staatstoezicht op de Mijnen [SodM], 2018).

\section{A "DISASTER IN SLOW MOTION"}

The combination of the shallow earthquakes, the compactionrelated subsidence of land basically at sea level, the weakness of the water saturated soil and soft sediments in the shallow 
subsurface, and the high level of fragility of the building stock, largely consisting of unreinforced masonry buildings, turned out to be an explosive mix leading to widespread and serious damage to buildings in the area on top of the gas field (Fig. 2). Currently, about $40 \%$ of the 400,000 people afflicted are confronted with some kind of damage to their homes (e.g., Postmes et al., 2018). Damage is not limited to occasional cracks in walls and floors. Entire buildings are slowly falling apart (Fig. 2), resulting from a complex interaction of causes, often triggered by even small earthquakes (e.g., van Staalduinen et al., 2018). That is why the Groningen people perceive the progressive deterioration of their built environment as a "disaster in slow motion."

For observers and investigative journalists following the Groningen case, it is apparent that this "disaster in slow motion" has been mismanaged by both the operator and the authorities (e.g., Tomale, 2015; Brandsma et al., 2016). People with damage to their properties were confronted with a seemingly endless process, first to get their damage recognized as damage caused by the gas extraction, and second to get the damage repaired or compensated. People worried that the value of their property would drop substantially, eventually imprisoning them in an unsellable house full of cracks. This distressingly slow process resulted in a lot of frustration and outrage and an increasing weakened sense of control by the people afflicted (e.g., Postmes et al., 2018).

On top of this exhausting battle with the operator and the authorities came an increasing sense of insecurity. After the 2012 Huizinge earthquake, a program of inspection began to assess the earthquake risk of the buildings in the area, from public buildings, such as school and hospitals, to private dwellings. This inspection program was the first step in a reinforcement program. Suddenly, people received assessment reports, in which they were told that they were living in a seismically unsafe house and that their house would probably have to be seriously retrofitted or even knocked down and replaced by a newly built house. In the current reinforcement program, a building is considered seismically unsafe if the risk is high that the building would collapse during an M 5.0 earthquake, still considered the maximum possible magnitude by the Koninklijk Nederlands Meteorologisch Instituut (KNMI; Dost et al., 2017). But because the effective retrofitting is a long-term project, possibly taking more than a decade, people suddenly do not feel safe in their own homes, now considered unsafe by experts. Each new earthquake, no matter how small, causes more distress. This sense of insecurity is further maintained by the lack of effective risk and science communication, contributing to an ever inflating perceived seismic risk by the people afflicted.

\section{SCIENTIFIC RESEARCH}

After the 2012 Huizinge earthquake, scientific research efforts were boosted, primarily to support the minister of economic affairs in making evidence-based decisions on the future of the gas production in Groningen. Research focused on the (a)

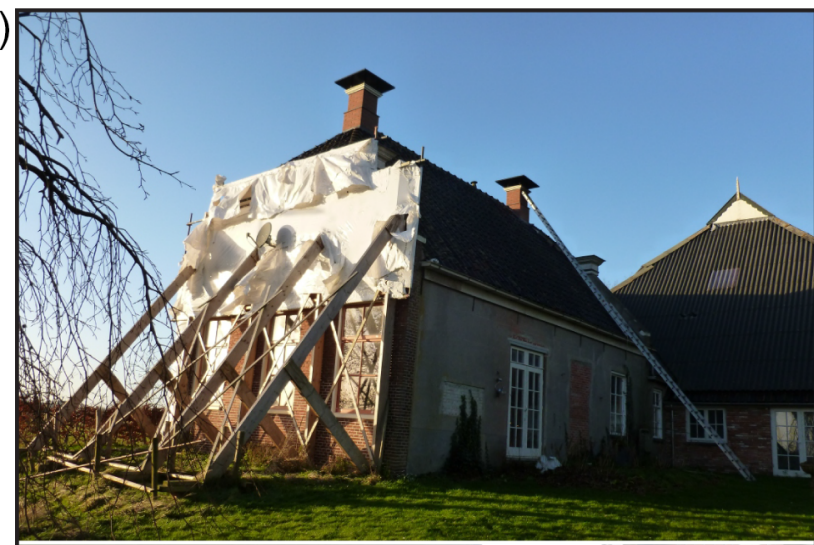

(b)

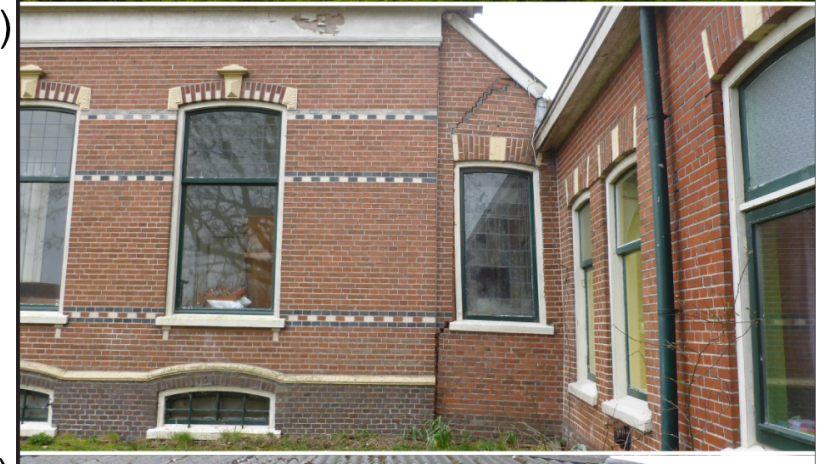

(c)

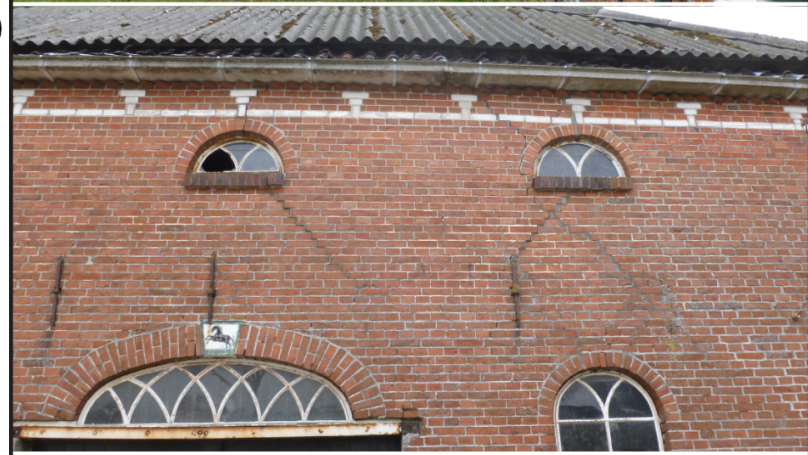

(d)

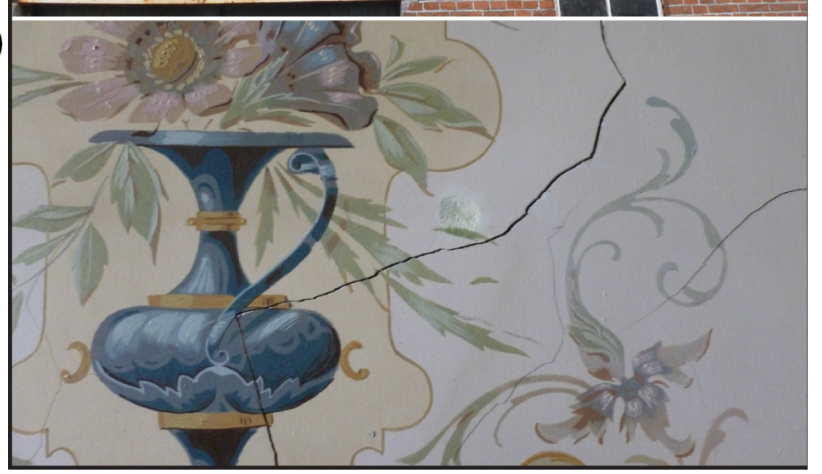

A Figure 2. Examples of damage in Groningen: (a) masonry farmhouse (Bedum) in scaffolding, a typical sight in Groningen; notice the fake iconic chimneys, taken as a first mitigation measure, (b) differential settling affecting a farmhouse (Godlinze) built on an artificial mound (called "wierde" in Groningen), (c) typical in-plane earthquake-related structural damage to a masonry wall of a barn (Godlinze), (d) cracks in painted plaster covering a masonry wall inside a farmhouse (Godlinze). The color version of this figure is available only in the electronic edition. 
relationship between the parameters of the gas extraction (e.g., volume, rate, and temporal variability) and the induced seismicity. The most important question, to date still unanswered, was whether or not a "safe" production level exists.

Besides a number of scientific institutes (e.g., KNMI, Nederlandse Organisatie voor toegepast-natuurwetenschappelijk onderzoek [TNO]), most of the research has been initiated and directed by the operator (NAM). This fact alone raised a lot of suspicion among the public, because the perception persisted from the beginning that "the butcher was inspecting his own meat," notwithstanding the fact that the operator disposes the most technical expertise with respect to the gas field. The cry for independent research only grew louder through the years. This perception was furthermore fed by politicians and activists, eventually resulting in an overall antiscientific public sentiment. Scientists in general, even those not directly involved, are perceived as being "on the wrong side." This antiscientific sentiment also contributes significantly to the science outreach failure.

The extensive research program primarily focused on the assessment of the seismic hazard and subsequently the seismic risk (e.g., Van Elk et al., 2017). Main topics dealt with were the classical probabilistic seismic hazard assessment (PSHA), the maximum magnitude, building fragility assessment (e.g., Crowley et al., 2017), and the risk assessment, on which eventually the entire reinforcement program was grafted.

Everyone agrees that scientific understanding of the induced seismicity in Groningen has improved significantly since the 2012 Huizinge earthquake, but the scientific community is still unable to give a conclusive answer regarding whether the seismicity can be controlled by managing the gas production. The uncertainties of the models are still too large to allow unambiguous advice to policymakers and transparent information to the public. Again, not being able to foresee the end of the "seismic terror" only feeds the antiscientific sentiment and the overall distrust and outrage among the people afflicted.

\section{SCIENCE OUTREACH FAILURE}

Based on my personal experiences and a proper analysis after five years involvement, I identified a number of examples that illustrate the failure of the scientific community in communicating, to the policymakers and public, both the advances made in the scientific knowledge and the consequences with respect to seismic hazard and risk.

\section{PSHA}

The true meaning of a probabilistic seismic hazard map, which expresses the annual probability of exceedance of certain peak ground acceleration (PGA), is already very difficult to understand for nonexperts, let alone for laypersons. A clear interpretation by experts is crucial. Both the KNMI and the NAM produce seismic hazard maps of the Groningen area, the former following a classical seismological approach on the basis of the (induced) earthquake record (Dost et al., 2017), and the latter starting from a compaction-based, seismological model
(Bourne and Oates, 2017), in which seismicity is forecast in relation to distinct production scenarios. Through the years, both seismic hazard maps have converged.

Since the 2012 Huizinge earthquake, the KNMI has produced four seismic hazard maps (2013, 2015, 2016, and 2017). They intend to provide an update every year. All these maps show the PGA has a $10 \%$ chance to be exceeded in a $50 \mathrm{yr}$ time period ( $475 \mathrm{yr}$ return period). Comparing the maps, two observations stand out that make sense to scientists but feed suspicion among the public. Although the 2013 and 2015 maps show nice elliptical contours (Dost and Spetzler, 2015), the 2016 (Spetzler and Dost, 2016) and 2017 (Spetzler and Dost, 2017) maps show a patchier occurrence. This remarkable change is primarily due to an improved ground-motion prediction equation (GMPE) that takes into account the details of the shallow subsurface in Groningen. Furthermore, in less than four years, the highest PGA value decreased for more than $50 \%$, from $0.42 g$ in 2013 to $0.22 g$ in 2017 , which indeed reflects the inherently nonstationary nature of the induced seismicity. Although the latter makes perfect sense for earthquake scientists, people perceived this stepwise decrease in PGA value as a deliberate attempt by compromised scientists to downplay the seismic risk. The situation only worsened when in 2015 the national coordinator, who is in charge of the reinforcement program, outlined the so-called "earthquake area" by using the $0.2 \mathrm{~g}$ contour of the $2015 \mathrm{KNMI}$ seismic hazard map (Nationaal Coördinator Groningen, 2015). Suddenly, this contour became a "hard" static boundary, excluding all people living outside the so-called "earthquake area" from any priority treatment with respect to the reinforcement. The absurdity of this measure quickly became apparent when earthquakes occurred outside the so-called "earthquake area," leaving the people afflicted in total confusion. Moreover, people did not understand why this $20150.2 \mathrm{~g}$ contour was retained in the reinforcement program, irrespective the subsequent updates of the seismic hazard maps that made the $20150.2 \mathrm{~g}$ contour completely obsolete. With hindsight, it is incomprehensible that the scientists involved did not, directly or through public fora (e.g., op-eds), confront the policymakers about their misinterpretation and misuse of the seismic hazard map, which only gave rise to a lot of confusion, distrust, and frustration among the public.

Although probabilistic seismic hazard maps can be of use in a reinforcement policy when correctly interpreted, in Groningen I experienced myself that these maps are basically useless in communicating seismic hazards to the public, primarily because people have difficulty understanding probabilities and coping with all the uncertainties involved. Communicating seismic hazard and risk to public and policymakers needs a different approach. An example of a more communicative approach in the case of induced seismicity has been developed by the U.S. Geological Survey; that is, the one-year seismic hazard forecast (e.g., Petersen et al., 2016). Furthermore, comparing the seismic risk with everyday risks can provide a more comforting message (e.g., Joffe et al., 2013). 


\section{Maximum Magnitude}

The scientific discussion on the maximum expected and maximum possible magnitude also turned out to have a negative effect on the overall inflated perceived risk among the people in Groningen. At first, prior to the 2012 Huizinge earthquake and the subsequent research program, no one had any clue of what the maximum magnitude could be. Since 2012, the KNMI considers a maximum possible magnitude of $\mathbf{M} 5.0$ (Dost et al., 2017). In 2017, a Senior Seismic Hazard Analysis Committee, commissioned by the operator NAM, agreed on a distribution of the $M_{\max }$, ranging from $\mathbf{M} 4.0$ to 7.0 , with the highest probability attributed to $\mathbf{M} 4.5$ and a weighted mean of M 5.0 (Bommer and Van Elk, 2017), which is in line with the $M_{\max }$ of the KNMI. Zöller and Holschneider (2016) calculated a maximum expected magnitude ranging from M 3.9 to 4.3 .

Although the scientists coped with the uncertainties of their $M_{\max }$ estimates, public and policy makers got stuck on the worst case scenario, an $\mathbf{M}$ 5.0 "Big One." In the communication of the national coordinator in the framework of the reinforcement program, emphasis was put on an M 5.0 earthquake. This focus in the reinforcement program results in a massive operation in which the majority of the buildings in Groningen will need a retrofitting to a certain degree (up to demolition and rebuilding). The impact of the first stages of this massive operation is becoming apparent in villages, where characteristic buildings are knocked down to be replaced by modern, earthquake proof buildings. Realizing the scale of this operation, people, in particular policymakers, are starting to question the reinforcement program. Remarkably, in the public perception, the fact that the M 5.0 earthquake is part of the PSHA is no longer interpreted as a probability that may never occur, but as a certainty, as the "Big One" that one day will happen. Whether or not such an earthquake is physically possible, has, in their perspective, become irrelevant.

In this respect, science has again contributed to an inflated seismic risk perception. That both policymakers and scientist play it safe by focusing on the worst case, that is, the maximum possible instead of maximum expected magnitude is most probably due to the large degree of uncertainty surrounding the estimates. The consequences are however major, both with respect to the reinforcement program and the perceived seismic risk. The focus on absolute safety, inferring extremely high-investment costs, has eventually led to a complete political and administrative deadlock with respect to the reinforcement program (e.g., Steckler et al., 2018).

\section{Transparency and Science Outreach}

Both the operator and the scientific institutes take pride in full transparency with respect to the results of their scientific research. All technical reports, scientific studies, and peer-reviewed publications, as well as raw data, are made available on their websites (e.g., Nederlandse Aardolie Maatschappij [NAM], 2018b). But what is lacking is an effort to popularize the science so that nonexperts can understand. The lay public is basically let down.
Transparency eventually backfired. By neglecting to interpret the "overload" of scientific information, reports and publications fell victim to cherry picking by nonexperts who lacked knowledge of basic concepts of earthquake science. An alternative public science was created that eventually took on a life of its own, completely disconnected from the true science. New scientific insights are systematically ignored, in particular when these insights refute aspects of the alternative public science (e.g., with respect to seismic hazard, maximum magnitude, building fragility). This alternative public science excels in simplicity. Moreover, it is inviting to the public by offering (false) certainties, contrary to the true science full of inconvenient uncertainties and probabilities. By systematically overemphasizing the worst-case scenarios, an "earthquake monster" emerges, feeding the inflated seismic risk perception among the public. Furthermore, the danger exists that politicians, bidding for the public's favor by advocating absolute safety, graft their policy on this alternative science.

The scientific community contented itself with so-called transparency, but failed to build a scientifically sound public science that enables the public to properly assess their personal risk perception and the policy makers to make relevant decisions. Under the pretext of transparency, the scientific community only generated more suspicion and distrust.

\section{Earthquake Preparedness}

Earthquake awareness and earthquake preparedness are crucial in any attempt to keep the seismic risk perception in proportion (e.g., Stewart et al., 2017). Moreover, it gives people a sense of control. Efforts have been made to provide online course material to elementary school in the area to raise children's earthquake awareness (Veiligheidsregio Groningen, 2016). Authorities have, however, been very reluctant to organize any large-scale public awareness event, such as a ShakeOut earthquake drill, primarily out of fear that this will spread panic among people already in fear of the worst. Moreover, people involved are not open to such awareness initiatives, because they generally consider the earthquakes as a problem the operator should resolve.

\section{LESSONS LEARNED}

In Groningen, I am convinced that science has become part of the problem, not the solution. First, the scientific community was unprepared when the 2012 Huizinge earthquake took everyone by surprise. Since then the scientific community has unsuccessfully tried to catch up with what is really going on in Groningen, not only in the subsurface but also in the built environment at the surface and the minds of the people afflicted. Second, science has been, and still is, completely expertled, focusing on technical and physical aspects related to the induced seismicity. Third, science communication has been a one-way transfer of scientific information, basically talking above the heads of the general public.

The Groningen case is exemplary of the concept of a "social seismic risk," as popularized by Sandman (1989). 
Although scientists view seismic risk as the product of "hazard $\times$ vulnerability ( $\times$ exposure)," people experience seismic risk as the product of "hazard $\times$ outrage $(\times$ exposure)" (Sandman, 1989). People in Groningen are indeed outraged because of the way they are treated by the operator and the authorities. Irrespective of the "real" seismic hazard, people overestimate the "perceived" hazard because they are outraged. In this context, trying to explain the "real" seismic hazard has little impact on the perceived social seismic risk. Only by tackling the issues causing public outrage (e.g., damage settlements, reinforcement), will the perceived hazard move in line with the "real," evidence-based, seismic hazard (Sandman, 1989).

The scientific community needs to decide on another risk communication strategy. The conventional "risk message model" (Demeritt and Nobert, 2014), which clearly failed in Groningen, should be replaced by a "risk dialogue model" (Stewart et al., 2017). Dialogues between scientists and the public and policymakers should not focus on the "matters of fact" but on the "matters of concern" (Stewart and Lewis, 2017). These "matters of concern" could also become drivers for bottom-up, community-led research in addition to expertled science (Stewart et al., 2017). Together with the people concerned, scientists should invest in building a public science, of which the public can claim ownership, and the scientists guarantee the scientific validity. By applying such a participatory approach, the scientists involved in the Groningen case would associate themselves with the Sendai Framework for Disaster Risk Reduction (United Nations International Strategy for Disaster Reduction [UNISDR], 2015). \&

\section{ACKNOWLEDGMENTS}

The author acknowledges both Editor-in-chief Zhigang Peng and the two anonymous reviewers for their constructive remarks and suggestions to improve this article, as well as for their impetus to pursue further interdisciplinary work on seismic risk management and communication.

\section{REFERENCES}

Bommer, J. J., and J. J. Van Elk (2017). Comment on "The maximum possible and the maximum expected earthquake magnitude for production-induced earthquakes at the gas field in Groningen, The Netherlands" by Gert Zöller and Matthias Holschneider, Bull. Seismol. Soc. Am. 107, 1564-1567.

Bourne, S. J., and S. J. Oates (2017). Development of statistical geomechanical models for forecasting seismicity induced by gas production from the Groningen field, Netherlands J. Geosci. 96, no. 5, s175s182.

Bourne, S. J., S. J. Oates, J. J. Van Elk, and D. Doornhof (2014). A seismological model for earthquakes induced by fluid extraction from a subsurface reservoir, J. Geophys. Res. 119, 8991-9015.

Brandsma, M., H. Ekker, and R. Start (2016). De Gaskolonie. Van nationale bodemschat tot Groningse tragedie, Uitgeverij Passage, Groningen, The Netherlands, 1-212 (in Dutch).

Crowley, H., R. Pinho, B. Polidoro, and J. Van Elk (2017). Developing fragility and consequence models for buildings in the Groningen field, Netherlands J. Geosci. 96, no. 5, s247-s257.

de Jager, J., and C. Visser (2017). Geology of the Groningen field-An overview, Netherlands J. Geosci. 96, no. 5, s3-s15.
Demeritt, D., and S. Nobert (2014). Models of best practice in flood risk communication and management, Environ. Hazards 13, no. 4, 313-328.

de Waal, J. A., A. G. Muntendam-Bos, and J. P. A. Roest (2017). From checking deterministic predictions to probabilities, scenarios and control loops for regulatory supervision, Netherlands J. Geosci. 96, no. 5, s17-s25.

Dost, B., and J. Spetzler (2015). Probabilistic seismic hazard analysis for induced earthquakes in Groningen; Update 2015, KNMI report, available at http://www.knmi.nl/kennis-en-datacentrum/publicatie/ probabilistic-seismic-hazard-analysis-for-induced-earthquakes-in-groning en-update-2015 (last accessed June 2018).

Dost, B., E. Ruigrok, and J. Spetzler (2017). Development of seismicity and probabilistic hazard assessment for the Groningen gas field, Netherlands J. Geosci. 96, no. 5, s235-s245.

Foulger, G. R., M. P. Wilson, J. G. Gluyas, B. R. Julian, and R. J. Davies (2018). Global review of human-induced earthquakes, Earth Sci. Rev. 178, 438-514.

Joffe, H., T. Rossetto, C. Solberg, and C. O'Conner (2013). Social representations of earthquakes: A study of people living in three highly seismic areas, Earthq. Spectra 29, no. 2, 367-397.

Keranen, K. M., and M. Weingarten (2018). Induced seismicity, Annu. Rev. Earth Planet Sci. 46, 149-174.

Klose, C. D. (2010). Human-triggered earthquakes and their impact on human security, in Achieving Environmental Security: Ecosystem Services and Human Welfare, P. H. Liotta, W. G. Kepner, J. M. Lancaster, and D. A. Mouat (Editors), NATO Science for Peace and Security Series-E: Human and Societal Dynamics 69, 13-29.

Nationaal Coördinator Groningen (2015). Meerjarenprogramma Aardbevingsbestendig en kansrijk Groningen 2016-2020, available at https://www.nationaalcoordinatorgroningen.nl/over-ons/documenten/ beleidsnotas/2015/december/16/meerjarenprogramma-ncg-dec-2015 (last accessed June 2018) (in Dutch).

Nederlandse Aardolie Maatschappij (NAM) (2018a). Feiten en cijfers, available at https://www.nam.nl/feiten-en-cijfers.html (last accessed August 2018) (in Dutch).

Nederlandse Aardolie Maatschappij (NAM) (2018b). Onderzoeksrapporten, available at https://www.nam.nl/feiten-en-cijfers/ onderzoeksrapporten.html (last accessed June 2018) (in Dutch).

Petersen, M. D, C. S. Mueller, M. P. Moschetti, S. M. Hoover, A. L. Llenos, W. L. Ellsworth, A. J. Michael, J. L. Rubinstein, A. F. McGarr, and K. S. Rukstales (2016). Seismic-hazard forecast for 2016 including induced and natural earthquakes in the Central and Eastern United States, Seismol. Res. Lett. 87, no. 6, 1327-1341.

Postmes, T., K. Stroebe, J. Richarson, B. LeKander, F. Greven, and J. Broer (2018). Gevolgen van bodembeweging voor Groningers: Ervaren veiligheid, gezondheid en toekomstperspectief 2016-2017, Heymans Institute, University of Groningen, Groningen, The Netherlands (in Dutch).

Rijksoverheid (2018). Kamerbrief over gaswinning Groningen, available at http://www.rijksoverheid.nl/documenten/kamerstukken/2018/03/29/ kamerbrief-over-gaswinning-groningen (last accessed June 2018) (in Dutch).

Sandman, P. M. (1989). Hazard versus outrage in the public perception of risk, in Effective Risk Communication, V. T. Covello (Editor), Putman Press, New York, New York, 45-49.

Schmidt, A., K. Boersma, and P. Groenewegen (2018). Management strategies in response to an institutional crisis: The case of earthquakes in the Netherlands, Public Administration 1-15, doi: $10.1111 /$ padm. 12516 .

Spetzler, J., and B. Dost (2016). Probabilistic seismic hazard analysis for induced earthquakes in Groningen, Update June 2016, KNMI Report, available at https://cdn.knmi.nl/system/data_center_publications/ files/000/052/460/original/Report_KNMI_hazard_map_V2.pdf (last accessed June 2018).

Spetzler, J., and B. Dost (2017). Probabilistic seismic hazard analysis for induced earthquakes in Groningen, Update June 2017, KNMI 
Report, available at https://cdn.knmi.nl/system/readmore_links/files/ 000/000/408/original/20170615_Technisch_rapport_hazardkaart_Groningen_ 2017.pdf (last accessed June 2018).

Staatstoezicht op de Mijnen (SodM) (2018). Gevolgen voor de veiligheidsrisico's en versterkingsopgave. Advies van Staatstoezicht op de Mijnen naar aanleiding van de afbouw van de gaswinning in Groningen, June 2018, SodM Report, available at https://www.sodm.nl/binaries/staatsto ezicht-op-de-mijnen/documenten/publicaties/2018/06/27/advies-overde-gevolgen-van-de-afbouw-van-de-gaswinning-in-groningen-voor-deveiligheidsrisios-en-versterkingsopgave/advies+SodM+over+veiligheidsrisi cos+groningen+juni+2018.pdf (last accessed August 2018) (in Dutch).

Steckler, M. S., S. Stein, S. H. Akhter, and L. Seeber (2018). The wicked problem of earthquake hazard in developing countries, EOS 99, doi: $10.1029 / 2018$ EO093625.

Stewart, I. A., and D. Lewis (2017). Communicating contested geoscience to the public: Moving from 'matters of fact' to 'matters of concern', Earth Sci. Rev. 174, 122-133.

Stewart, I. A., J. Ickert, and R. Lacassin (2017). Communicating seismic risk: The geoethical challenges of a people-centred, participatory approach, Ann. Geophys. 60, fast track 7, doi: 10.4401/ag7593.

Tomale, M. (2015). Bevingen. Aardbevingen in Groningen. GevolgenErvaringen-Emoties, Uitgeverij Leander, Groningen, The Netherlands, 1-256 (in Dutch).

United Nations International Strategy for Disaster Reduction [UNISDR] (2015). The Sendai Framework for Disaster Risk Reduction 2015-2030, available at http://www.preventionweb.net/files/ 43291_sendaiframeworkfordrren.pdf (last accessed June 2018).
Van Elk, J., D. Doornhof, J. J. Bommer, S. J. Bourne, S. J. Oates, R. Pinho, and H. Crowley (2017). Hazard and risk assessments for induced seismicity in Groningen, Netherlands J. Geosci. 96, no. 5, s259-s269.

van Staalduinen, P. C., K. C. Terwel, and J. G. Rots (2018). Onderzoek naar de oorzaken van bouwkundige schade in Groningen. Methodologie en case studies ter duiding van de oorzaken, July 2018, TU Delft Report, available at https://www.nationaalcoordinatorgroningen .nl/binaries/nationaal-coordinator-groningen/documenten/rapporten/ 2018/juli/11/rapport-onderzoek-oorzaken-schade/Onderzoek+oorzaken +bouwkundige+schade+Groningen+-+TU+Delft+CITG-CM-2018-01+11 $+j u l i+2018$.pdf (last accessed August 2018) (in Dutch).

Veiligheidsregio Groningen (2016). Aardbevingenwijzer, available at http://aardbevingenwijzer.nl (last accessed June 2018) (in Dutch).

Zöller, G., and M. Holschneider (2016). The maximum possible and the maximum expected earthquake magnitude for production-induced earthquakes at the gas field in Groningen, The Netherlands, Bull. Seismol. Soc. Am. 106, 2917-2921.

Manuel Sintubin KU Leuven

Department of Earth and Environmental Sciences Celestijnenlaan 200E BE-3001 Leuven, Belgium manuel.sintubin@kuleuven.be

Published Online 3 October 2018 